\title{
RISK AND FOREIGN DIRECT INVESTMENT IN ROMANIA
}

\author{
Cătălin Drob \\ „Vasile Alecsandri” University of Bacau \\ catad@ub.ro
}

\begin{abstract}
This paper tries to present the main categories (types) of risks that affect the inflows of foreign direct investment (FDI) in Romania, such as: country risk, political risk, economic risks, sovereign risks and so on. FDI is an important factor contributing to the economic development and to the economic growth of a country. In order to recuperate its economic handicap as compared to the other countries in the EU, Romania needs a massive inflow of foreign capital, especially in the form of direct investment. The paper also presents the evolution of FDI inflows in Romania and how they were influenced by the main factors affecting the FDI. In principle, between risk and the level of FDI inflows there is a direct dependency relationship: the higher the risk is in a country, the lower the level of FDI inflows is in that country. This is demonstrated by the empirical studies regarding FDI. These studies show that countries with high risk have major difficulties in attracting foreign investment. Therefore, it is important to identify very precisely the main risks that may affect the level of FDI inflows in Romania, in order to propose and implement strategies to mitigate these risks and to attract more foreign direct investment in Romania.
\end{abstract}

\section{Keywords}

economic development; risks; crisis; foreign direct investment; economic growth; Romania

\section{JEL Classification}

O11; P45

\section{Introduction}

According to the IMF's Balance of Payments and International Investment Position Manual 6th Edition (2009), along with OECD's Benchmark Definition of Foreign Direct Investment 4rd Edition (2008), FDI is defined as: "direct investment is a category of cross-border investment associated with a resident in one economy (the direct investor) based on control and influence".

As stated by IMF in the Balance of Payments and International Investment Position Manual 6th Edition (2009), a direct investment enterprise is considered "an entity subject to control or a significant degree of influence by a direct investor”.

FDI is considered an important factor contributing to the economic development and to the economic growth of a country. Therefore, in order to recuperate its economic handicap as compared to other developed countries from EU, Romania needs of important inflow of foreign capital, especially in the form of direct investment, so as Drob and Mironescu has shown (2007).

In order to explain the dynamic of the international investments' development have been developed several theories. Maybe, the most known theory concerning FDI is the "OLI" (ownership, location and internalization) theory (paradigm/model) proposed by John H. Dunning.

As stated by Dunning (1997), FDI are determined by three main factors (advantages):

- the advantage of ownership right, especially concerning intangible assets; 
- the advantage of internalization (if is cheaper to manufacture the product abroad instead of selling the production license to a company abroad;

- the advantage of the location (if the manufacturing of the products abroad is more profitable than exporting those products).

Also, Dunning (1997) has identified four main categories of motivation for investment abroad: resource-seeking, market-seeking, efficiency-seeking and capability-seeking.

The theories concerning FDI considered that the most important factors which determined the level of FDI are:

- $\quad$ the labor costs in the host country relative to the origin country;

- the management skills and the level of qualification of the workforce in the host country.

- the size of demand/market of the host country;

- the level of economic and infrastructure development of the host country;

- the level of taxes/incentives in the host country;

- the geographical distance between host country and origin country etc.

\section{Risks of FDI}

The notion of risk is defined in theory, in different mode, but almost all the definitions about risk underline the fact that the risk is linked by uncertainty and by probability (the probability of occurrence of an event). For example, ISO 31000:2009 defines risk as "effect of uncertainty on objectives" as stated by International Organization for Standardization (2009).

No matter how well managers are informed, they can't eliminate the uncertainty and implicitly the presence of the risk. Therefore, it is necessary to take into account all type of risks in the moment in which managers take investment decisions.

Relationship between FDI and risk is very complex. In the case of FDI, must be taken into consideration the specific risks from the country in which will be realized these investments. These risks generate so-called country risk. The country risk refers to the overall risk faced a foreign investor. This is a composite concept that includes several categories of risks as stated by Meldrum (2000):

- political risk;

- expropriation risk;

- economic risk;

- transfer risk;

- $\quad$ sovereign risk;

- $\quad$ exchange rate risk;

- location or neighborhood risk.

Political risk can be defined as an adverse consequence to certain political events. Factors that determine the size of this risk are:

- democracy;

- political (in)stability;

- $\quad$ control degree of the market by the state;

- $\quad$ size of the public sector;

- $\quad$ existence and manifestation of nationalist groups and / or terrorist;

- corruption;

- $\quad$ relations with neighboring countries;

- (in)stability in neighboring countries etc.

Some authors consider that political risk includes, among others, the risk of expropriation or nationalization.

Political risk can be divided into two categories: macro political risk and micro political risk. If the macro political risk affects all FDI (at the country host level), the 
micro political risk affects only several FDI with specific characteristics like nationality, activity domain, geographical area etc.

Political risk is one of the major risks that affect the inflow of FDI but not all factors that determine the size of this risk affect the inflow of FDI in the same way. The most important factors concerning political risk that attracts FDI are: political stability, democracy, low-level corruption, lack of internal ethnic and political tensions etc.

Economic risk can be defined as the risk of occurrence of a major change in economy or concerning economic growth rate, which would have major consequences, especially in terms of the expected return of foreign investment.

Factors that determine the size of this risk are: the inflation rate, the GDP size, the size of wage costs, the volume and structure of domestic production, the volume and structure of imports and exports, etc. For example, a high inflation rate in the host country affects the future return of foreign investment because this return will be smaller due to high inflation.

Transfer risk is the risk that can be generated by a government decision to restrict capital movements (repatriation of profits, dividends or capital). If in country host, the transfer risk is high, the foreign investor is not very interested to invest in this country.

Sovereign risk is the risk that may occur when the host government to foreign direct investment does not meet its financial obligations related to a government loan or related to a loan / credit guaranteed by government.

Exchange rate risk is defined as a consequence of exchange rate variability on the company's value and on its business operations. High exchange rate variability affects the FDI because it's very difficult to realize a realistic financial plan for these FDI.

Some authors take into account other categories of risk: financial risk and commercial risk. Financial risk show the risk that a country will not be able to repay its foreign liabilities and commercial risk is viewed as "the aggregated effects of operational, business and financial risks”, so as Gentile and Valahu has shown (2003).

\section{Country Risk Assessment}

At the international level, the country risk assessment is made by some commercial suppliers of country risk information such as:

- Bank of America World Information Services;

- Business Environment Risk Intelligence (BERI) S.A.

- $\quad$ Control Risks Group (CRG);

- $\quad$ Economist Intelligence Union (EIU);

- $\quad$ Euromoney Magazine;

- $\quad$ International Country Risk Guide (ICRG);

- Political Risk Services etc.

Political risk services is a model for assessing political and country risk and International Country Risk Guide is a method used to assess political, financial and economic risk.

The other way whereby foreign investors can assess the country risk is through sovereign ratings. The most known ratings agencies which provided is sovereign ratings are Standard \& Poor's, Moody's Investor Services and Fitch Ratings.

The Standard \& Poor's agency use a combination of upper letters (A, B, C and D ) and signs "+" and "-" to designate the country rating (is used a scale from AAA to $D)$. The highest rating (AAA) represent the lowest probability of default (D). The Moody's Investor Services agency use for scoring combinations of letters (A, B, C, a, $\mathrm{b}$ and c) and numbers (1,2 and 3). For example, for Moody's Investor Services agency, Aaa - means the lowest risk and $\mathrm{C}$ - means the highest risk. 
When a company intends to invest abroad, it may take into account an indicator (index) proposed by the Heritage Foundation: Index of Economic Freedom. This index measures economic freedom of countries based on trade, business and investment freedom. Depending on the value of this index, the economies of countries can be considered free (score between 100 - 80), mostly free (score between 79,9 70), moderately free (score between 69,9 - 60), mostly unfree (score between 59,9 50 ) or repressed (score between $49,9-0$ ).

\section{Risk and FDI in Romania}

For foreign investors, Romania is a destination heeded that offers a number of advantages such as:

- $\quad$ Big domestic market in this region of the world;

- $\quad$ Skilled labor and relatively cheap;

- $\quad$ Member country of N.A.T.O. and U.E.;

- Legislation compatible with the acquis communautaire;

- $\quad$ Lack of ethnic tensions.

Even if, theoretically, there are many arguments in favor of the decision to invest in Romania, in a report elaborated by the World Bank in 2013 (Doing Business Reports), Romania is only 72nd in the world in terms of the ease with which it can doing business in our country.

After 1989, the evolution of FDI in Romania was at first quite shy. Thus, between 1990 and 2000, the cumulated amount of FDI in Romania reached the level of \$7,3 billion, level that was far away from the real potential of the economy and from the level registered of neighboring countries at that time: Poland (\$39 billion), Hungary (\$21,5 billion) Czech Republic (\$12,5 billion), as Drob and Mironescu has shown (2007).

This low level of FDI registered between 1990 and 2000 can be explained through the distrust of foreign investors, which was caused by the uncertainty of investment and business environment, by unstable legal, institutional and politic frame, by corruption, by bureaucracy etc.

Since 2004, there has been a spectacular increase in the level of FDI in Romania. This increase can be explained by the increased confidence of foreign investors in the Romanian business environment, an important role being Romania's integration into NATO and EU structures. Another explanation for the increased volume of FDI inflows is to create the legal framework to promote direct investment with significant impact on the economy.

In 2008 has recorded the absolute level in terms of foreign direct investments in Romania (9.5 billion Euro). Getting this record was based on improving the business environment, the introduction of the flat tax, increasing the confidence of foreign investors in Romania.

In the coming years, with the onset of the global financial crisis, in Romania, the volume of FDI inflows declined drastically. Although the local economy recovered in 2011, foreign investors rushed to come to Romania. This caution is due, first, uncertainty about the global economy and regional. Evolution of FDI in Romania is shown in the following figure: 


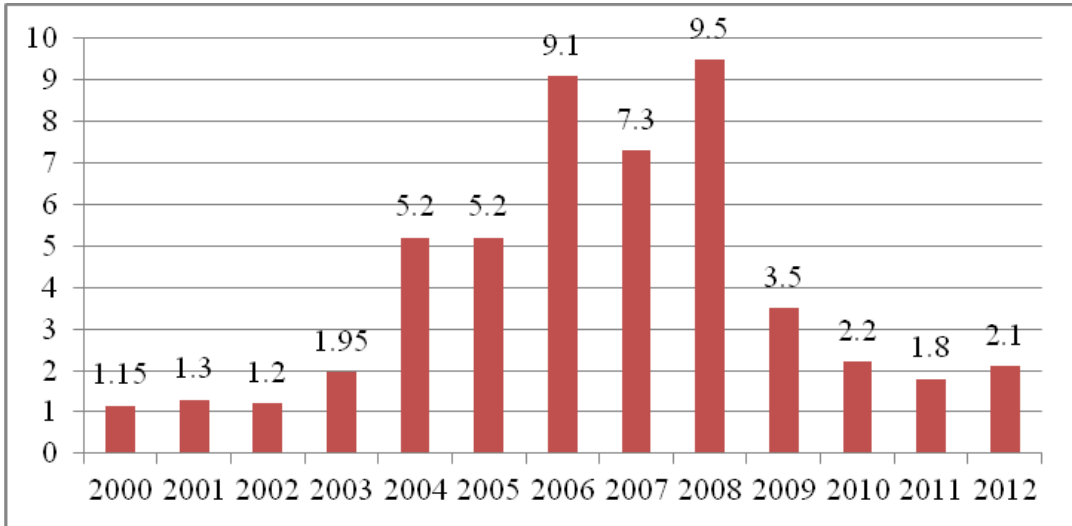

Figure 1 The evolution of FDI between 2000 and 2012 in Romania (EUR billion)

Many experts believe that the global financial and economic crisis is far from over. In these circumstances, foreign investors are quite cautious and less willing to invest in this region of the world in general and Romania in particular.

Regarding Romania's country risk assessment by rating agencies, lately observed an improvement in the rating of our country by international rating agencies. With Romania's Euro-Atlantic integration, international agencies revised their assessments of our country. Currently, the major international rating agencies include Romania in the category of countries recommended as a potential destination for foreign investment. For example, in 2014, Standard \& Poor's (which was the agency most demanding in terms of sovereign risk assessment of Romania) has improved Romania's rating from "BB +" to "BBB -" (from "junk" category to "investment grade" category). This rating increase is a signal that the investment risk in Romania is becoming smaller.

In the 2014 ranking based on the indicator proposed by the Heritage Foundation (Index of Economic Freedom), Romania is among the countries with economies "moderately free" (ranked 62 with 65.5 points) with Poland (ranked 50 t with 67 points), Hungary (ranked 51 with 67 points) and Bulgaria (ranked 61 with 65.7 points). The current position is for Romania one satisfactory if we consider that in 2005 our country was framed by the Heritage Foundation in the category of countries with "not free" economy.

Also in 2014, the company COFACE considered to be the leading company in the field of credit insurance has published its ranking of countries according to country risk. In this ranking, Romania is included in the category of countries with unstable economic environment. According COFACE, in present, in Romania, the political instability, the low absorption rate of European funds and the corruption are considered among the main factors that affect investment environment.

From the above it follows that in assessing country risk and can be used several methodologies. Every company or agency specializing in country risk assessment uses its own methodology. However, regardless of the company that made the country risk assessment and regardless of methodology used, can be observed, in general, in recent years, growth for Romania's rating. This growth for Romania's rating can explain, to a point, increasing of the volume of FDI in our country until 2008. Though Romania's country risk remained at a satisfactory level after 2009, FDI volume decrease can be attributed mainly due national and international economic environment still confused by strong economic and financial crisis. 


\section{Conclusions}

Relationship between FDI and risk is very complex due to many factors that determine country risk. In principle, the higher country risk is, the lower is the appetite for foreigners to invest in that country.

Country risk can be decomposed into several categories such as: political risk, economic risk, and transfer risk, sovereign risk etc. In recent years, Romania has improved much in the eyes of foreign investors. Romania's country risk fell considerably and thus the risk of investing in Romania has become smaller. This has seen growth year on year, until 2008, FDI inflows in Romania. After 2008, with the onset of the global financial crisis, the FDI inflows dropped significantly, almost every year, compared to the record level achieved in 2008. This significant decrease can be attributed to some risk factors, particularly political factors (political instability, corruption) and economic factors (uncertainty about the evolution of regional and national economy, etc.) that affect quite strongly the economic and investment environment in Romania.

After all, foreign investor is the one who decides where, when and how to invest. This decision may be based on the risk of the country in which wants to invest, but it matters a lot the inclination toward risk of the investor. Assuming a high risk may be the cause of a big failure but also may be the cause of a resounding success.

\section{References}

Drob, C. (2007), Theoretic aspects concerning foreign direct investment, MOCM, No.13, Volume II, p. 207-210, Bacau, Alma Mater Publishing House.

Drob, C. (2011), General and specific aspects regarding the relationship between uncertainty, irreversibility and investment, Journal of Engineering Studies and Research, No.4, Volume 17, p. 41-44, Bacau, Alma Mater Publishing House.

Drob, C., Mironescu, R. (2007), The evolution of the foreign direct investment in Romania, MOCM, No.13, Volume II, p. 211-214, Bacau, Alma Mater Publishing House.

Dunning, J. H. (1977), Trade, Location of Economic Activity and the MNE: A Search for an Eclectic Approach, in Bertil Ohlin, Per-Ove Hesselborn, and Per Magnus Wijkman, eds., The International Allocation of Economic Activity, p. 395-418, London.

Gentile A., Valahu, P. (2003), Political risk insurance helps investors push projects ahead, The US-China Business Council.

International Monetary Fund (2009), Balance of Payments and International Investment Position Manual, 6th Edition, Washington, DC, USA.

International Organization for Standardization (2009), ISO 31000:2009: Risk Management - Principles and Guidelines, Geneva, Switzerland.

Meldrum, D.H. (2000), Country risk and foreign direct investment, Business Economics, Vol. 35, p. 33-40.

Organisation for Economic Co-operation and Development (2008), OECD Benchmark Definition of Foreign Direct Investment, OECD Publishing, Paris, France. 